\title{
Precision Agriculture and Carbon Sequestration - Need of an Hour in Current Climate Changing Scenario
}

\author{
Aminuddin Qureshi ${ }^{1 *}$, Amrinder Kumar ${ }^{2}$ and Jeevan Lal Nag ${ }^{1}$ \\ ${ }^{1}$ College of Agriculture and Research Station, Kanker, Indira Gandhi Krishi Vishwavidyalaya \\ Chhattisgarh-494334, India \\ ${ }^{2}$ Department of Agronomy, Dr. Rajendra Prasad Central Agricultural University, Pusa
}

(Samastipur), Bihar, India

*Corresponding author

\begin{tabular}{|c|}
\hline Keywords \\
\hline $\begin{array}{l}\text { Climate change, } \\
\text { Carbon sequestration, } \\
\text { Smart agriculture, } \\
\text { Climate resilient } \\
\text { Agriculture }\end{array}$ \\
\hline Article Info \\
\hline $\begin{array}{l}\text { Accepted: } \\
17 \text { January } 2018 \\
\text { Available Online: } \\
\text { 10 February } 2018\end{array}$ \\
\hline
\end{tabular}

A B S T R A C T

India has been able to produce enough to feed its $1.25+$ billion As well as export food grains to other countries. But the challenge to feed a Projected population of 1.6 billion in 2050 and provide them with nutrition Security, is a formidable one because of the continuously degrading natural resource base and shrinking of good agriculture land for cultivation, It has been estimated that to meet the demands of that vast population, land productivity has to be enhanced four times along with three fold increase is water productivity and concomitant increase of six times in labour productivity. The era of Anthropocene has been endorsed by both climatic and non-climatic factors. It may increase the risk of food and water security across the globe. Among all, carbon (C) sequestration is one of the important strategies that could mitigate the effect of climate change to some extent by transferring atmospheric $\mathrm{CO}_{2}-\mathrm{C}$ into the long- live natural pools such as soils and perennial green biomass. Soil organic carbon (SOC) has relation in plant growth and agronomic productivity Most of the soils of India have been depleted their SOC stocks. Further, changes in climate are exacerbating the risk of soil erosion and alter nutrient cycling, and thereby impacting optimization of crop production. Therefore, conservation of sol organic matter (SOM) is essential to prevent soils from further degradation and for overall soil health maintenance. This article focuses climate change impact on agriculture, $C$ Sequestration and their role on vice-VERSA. The strategies for C sink (efficient use of crop residue, conservation agriculture, integrated nutrient management, agroforestry, cover crop, use of organic and other bio-solids etc.) along with soil $\mathrm{C}$ which will have marked influence on sustainable crop production and impart climate resilience.

\section{Climate change is reality}

Global warming, caused by the increase in concentration of GHGs in the atmosphere, has emerged as the most prominent environmental issue all over the world. These GHGs viz.
Carbon Dioxide $\left(\mathrm{CO}_{2}\right)$, Methane $\left(\mathrm{CH}_{4}\right)$ and surface and thus raise the atmospheric temperature. The Inter-Governmental Panel on Climatic Change (IPCC), in its Fifth Assessment Report, has reiterated that warming of the climatic system is 
unequivocal. The anthropogenic influence on the climatic system is evident from the increasing concentrations of GHGs in the atmosphere and the positive radiative forcing. As a result, the temperature atmosphere and ocean is going up, snow and ice are melting fast, and sea level is of rising. This global climate change will have considerable impact on the crop, soil, livestock and fishery.

Agriculture engages almost two-third of the workforce in gainful employment and accounts for a significant share in India's gross domestic product. Several industries depend on agricultural production for their requirement of raw materials. Due to its close linkages with other economic sectors, agricultural growth has a multiplier effect on the entire economy of the country. The agricultural sector is believed to contribute to the greenhouse effect and the ensuring climate change is likely to have adverse impact on this sector, Various agricultural activities such as land clearing, cultivation of crops, irrigation, animal husbandry, fisheries and aquaculture have a significant impact on the emission of GHGs and consequently on climate change (IPCC, 2014). An in-depth understanding of trends in emission of GHGs, their driver, and the relation between the two, is essential for comprehending the need for mitigation and adaptation. The objectives of this paper are to evaluate the emission of GHGs from Indian agriculture, analyze the drivers and trends of GHG emission and assess the potential of various mitigation options.

\section{Agriculture as a source and sink of GHG}

Agriculture contributes to greenhouse effect primarily through the emission and consumption of GHGs such as $\mathrm{CH}_{4}, \mathrm{~N}_{2} \mathrm{O}$ and $\mathrm{CO}_{2}, \mathrm{CH}_{4}$ is produced in soil during microbial decomposition of organic matter under anaerobic conditions. Rice fields submerged underwater are the potential sources of $\mathrm{CH}_{4}$ production. Continuous submerged, higher organic $\mathrm{C}$ content and use of organic manure in Puddled soil enhance $\mathrm{CH} 4$ emission. Burning of crop residues also contributes to the global methane budget. The enteric fermentation in ruminants is another major source of $\mathrm{CH} 4$ emission.

Nitrous oxide is produced in soils through the processes of nitrification and denitrification. Nitrification is the aerobic microbial oxidation of ammonium to nitrate, and denitrification is the anaerobic microbial of nitrate to nitrogen gas $\left(\mathrm{N}_{2}\right)$ Nitrous oxide is a gaseous intermediate in the reaction sequence of denitrification and a by- product of nitrification that leaks from microbial cells into the soil and ultimately into the atmosphere. One of the main controlling factors in this reaction is the availability of inorganic $\mathrm{N}$ in soil through additions of synthetic or organic fertilizers, manure, crop residues, sewage sludge or mineralization of $\mathrm{N}$ in soil organic matter following drainage/ management of organic soil and cultivation / lands-use change on mineral soils. The main source of carbon dioxide in agriculture is tillage, which triggers emission of this gas though biological decomposition of soil organic matter. Tillage breaks the soil aggregates, increases the oxygen supply and exposes the surface area of organic material promoting the decomposition of organic matter. Use of fuel for various agricultural operations and burning of crop residues are the other sources of carbon dioxide emission. An off-site source is the manufacturing of farm implements, fertilizers and pesticides.

Climate change is becoming a serious global environmental concern. The signatures of climate change, have been seen in every sphere of life on the earth which ignited the issues towards set back free and eco-friendly environment. The climate has been changing 
naturally as volcanoes, tectonic plate movements since the beginning of time. Recently it is in the news due to anthropogenic emissions and man-made disturbances. Concentrations of GHGs in the atmosphere exceeded the pre-industrial levels by about 40, 150 and $20 \%$ in $2011 \mathrm{CO}_{2}, \mathrm{CH}_{4}$, $\mathrm{N}_{2} \mathrm{O}$, Respectively. The current total global anthropogenic emission is estimated at 400 ppm (WMO, 2013).

It was expected that increase in atmospheric $\mathrm{CO}_{2}$ has a fertilization effect on crops through carbon(C) assimilation pathway and thus may encourage crop growth and productivity (Srinivasa Rao et al., 2016). On the other hand, increase in temperature could reduce crop growth and periods, alter photosynthetic processes, and affect pest populations, nutrient loss in soils. The transfer of $\mathrm{C}$ in the green biomass and its sink into the soils is one of the most important strategies to address the problem of land degradation and climate change mitigation. Secondly, $\mathrm{CO}_{2}$ concentration in the atmosphere can be minimised by reducing the global energy use or through the substitution of fossil fuels by biomass and sequestering $\mathrm{CO}_{2}$ in soils and biomass (Schrag, 2007). SOC refers to containing $\mathrm{C}$ in SOM; hence, conservation and agricultural soils have list 30 to $75 \%$ of their antecedent SOC pool (Lal et al., 2007). Agricultural, forest and other land- use change (AFOLU) contributes less than 25\% ( 10-12 Gt $\mathrm{CO}_{2}$ eq/year) of anthropogenic GHG emission. Long-term experiments are important for assessing long-term changes in SIC and crop yields and estimating C sequestration potential of agricultural lands (Srinivasa Rao et al., 2013).

\section{Carbon sequestration $-a$ route to sustainable life}

Water and agrochemicals (fertilizer, pesticides, herbicides etc.) are vital inputs in the agricultural production system. Water, the most vital of them, is becoming scarcer each passing say. The country became 'water stressed' in 2007 and if the 'business as usual scenario' continues, the entire country may became 'water scarce' by 2050 . It is estimated that only a handful of basins will have per capita water availability above the critical level by 2025. The irrigation projects developed at a very huge cost to the exchequer, function at an efficiency level of 38-40 per cent. Mismanagement of water ultimately leads to degradation of natural resources. In spite of a plethora of technologies available like drip and sprinkler having water application efficiency between $60-90 \%$ water use efficiency continues to be low. The latest estimates put the area under drip and sprinkler irrigation system around 7.8 million ha out of a potential of $69-5 \mathrm{~m}$ ha. It has been established that increase in water use efficiency automatically results in increase in nutrient use efficiency. A typical example is drip fustigation which leads to a quantum saving of at least $40 \%$ fertilizers applied.

Use efficiency of fertilizer nitrogen, which constitutes more than $60 \%$ of total plant nutrients consumed in India is abysmally low; $30-40 \%$ in rice and $40-60 \%$ in other crops. Excessive use of nitrogenous fertilizers in leading to ground water pollution as well as increased $\mathrm{N}_{2} \mathrm{O}$ emission. Nitrogen use efficiency can be increased by treating urea with nitrification inhibitors or coating with some hydrophobic substances to retard the release of urea in soil solution or its microbial oxidation to nitrates, which leach down or are lost to the atmosphere as $\mathrm{N}_{2}$ or $\mathrm{NO}_{2}$ gases. The Global Warming Potential (GWP) of $\mathrm{NO}_{2}$ is about 310 times that of $\mathrm{CO} 2$. Phosphorus use efficiency is even lower at $15-20 \%$ while that of micro nutrients is dismally low varying between 2-5\% Such low use efficiencies lead to considerable financial losses to the 
exchequer and cause serious environmental hazards. Development of crop-region specific customized fertilizers is needed to nutrients like boron, copper, manganese and molybdenum has to be done cautiously because of a narrow margin between the deficiency and toxicity thresholds of these nutrients. We have to do away with the conventional form of agriculture that focuses on Recommended Dosage of Fertilizes with emphases on NP only. Soul Health Card Scheme provides ample opportunity to switch over to site specific nutrient management immediately. Precision farming is tailored to provide the exactly needed amount of a specific input at given location.

The high production levels have to be not only sustained but also achieved with emphasis on energy savings and low emission technologies considering climate change impacts. These aspects have not been factored in the projected production estimates of various commodities. The year 2015 had been the warmest year on record with 2016 aiming to break this record. Annual $\mathrm{CO} 2$ concentrations crossed the $400 \mathrm{ppm}$ level in 2015 and rainfall is becoming more erratic with higher variability

Obviously higher amount of inputs would be needed to obtain the same levels of productivity. Technology-driven farming is the only option for increasing farmers' income and reducing cultivation costs with the ultimate aim of shifting to precision farming. Unfortunately, more than $80 \%$ of the farmers fall in the small and marginal category. Small sized farms coupled with scattered holdings will be a major hindrance in switching over to precision farming as it involves a seamless merging of remote sensing, GIS, GPS, sophisticated machinery and sensors for application of various inputs in measured quantities varying over space and times.
The Government's decision to use drone technology for estimating crop yields and damage is an indication of its intention to use modern technologies in agriculture. Precision faming is already fairly common in developed nation like USA. Australia and several European Countries where the focus is on cost cutting. Minimal environmental damage and high quality produce. It is now possible to differentiate between stresses caused by different nutrients through hyper spectral signatures.

Smart phone controlled drip system is no larger a distant goal. Flying drones have already entered the domain. Can self-driving tractors, robotic harvesters, integration of data technology into day to day operations in the digital era, field level data collection by sensors attached to tractors or installed in the field, be far behind? The sooner we shift to personalized farming, the faster will be reduction in environmental foot prints, productivity enhancement in a sustainable manner and moderation of climate

\section{Climate smart agriculture and carbon sequestration}

Climate smart agriculture practices include mulching, incorporation of crop residue, intercropping, conservation agriculture, crop rotation, integrated crop-livestock management, agro-forestry, improved grazing and improved water management. Through these resources conservation practices can reduce soil $\mathrm{C}$ losses by decreasing erosion, reducing oxidation of SOM and providing $\mathrm{C}$ inputs. Restoration of soil biota and their ecological processes breaks down organic matter into SOC fractions and stable organomineral complexes. In addition, such practices contribute to improve soil fertility and productivity. The global potential of SOV sequestration rate is estimate at 0.6 to $1.2 \mathrm{Gt}$ $\mathrm{B}$ yeat-1, comprising 0.4 to $0.8 \mathrm{Gt} \mathrm{C}$ year $^{-1}$ 
through adoption of recommended management practices on cropland soils, 0.01 to $0.03 \mathrm{Gt} \mathrm{V}$ year $^{-1}$ on irrigated soils and 0.01 to $0.3 \mathrm{Gt} \mathrm{C}$ year $^{-1}$ through improvement of rangelands and grasslands (Lal et al., 2007). Long-term manure application increases the soil $\mathrm{C}$ pool and the effects may persist for longer periods. Although both organic and inorganic forms of $\mathrm{C}$ are found in soils, land use management typically has a larger impact on SOC (Srinivasarao et al., 2014).

\section{Climate change adaptation and mitigation in agriculture}

Need to adopt resource conservation technologies such as no-tillage, direct seeding of rice and crop diversification.

Crop residue management without affecting crop-livestock systems.

Use of short duration leguminous pulses and oilseed crops which can cope with intermittent dry spells.

Efficient water use such as frequent but shallow irrigation, drip and sprinkler irrigation for high value crops, irrigation at critical stages.

Soil and water conservation practices such as ridges and furrows, land grading and leveling, field bunds, graded line bunds, contour trenching, conservation furrows, mulching and judicious application of Farm Yard Manure (FYM).

Nutrient management practices should be followed for increasing the use efficiency of nutrients such as INM, optimum use of fertilizer doses, split application of nitrogenous and potassic fertilizers, deep placement, use of nitrification inhibitors for preventing loss through volatilization and leaching.

\section{Way forward}

Coping with the adverse impact of climate change on agriculture will require careful management of natural resources like soil, water and biodiversity. Agriculture is the most sensitive sector to the climate change. Soil C sequestration is a win-win approach which can deal both adaptation and mitigation. Therefore, restoration of waste and degraded lands and ecosystems through adopting of improved management practices can enhance SOC and improve soil quality and health. Improving organic matter in soil will increase water holding capacity of soil which helps to cope up with intermittent dry spell, in the other hand it will release the nutrient in more judicious way which ultimate smart agriculture practices such as conservation agriculture, inter cropping, crop rotations, improve cultivars, INM, soil and water conservation can increase $\mathrm{C}$ sequestration in soils have been established hypothetically; however it requires field measurements for validation these concepts.

\section{References}

IPCC (2013)."Climate Change 2013: The Physical Science Basis;" In: Contribution of Working Group In to the Filth Assessment Report of the Intergovernmental Panel on Climate Change. (Stocker, T.F., Qin, D., Plattner, G.K., Tignor, M., Allen, S.K., Bosching, J., Nauels, A., Xia, Y., Bex, V. and Midgley, P.M. Eds.) pp.1535, Cambridge University Press, Cambridge, United Kingdom and New York, NY, USA.

IPCC (2014). Climate Change: Mitigation of Climate Change. Contribution of Working Group III to the Fifth Assessment Report of the Intergovernmental Panel on Climate Change [Edenhofer, O., R. Pichs- 
Madruga, Y. Sokona, E. Farahani, S. Kadner, K. seyboth, a. Adler, I. Baum, S. Brunner, P. Eickemejer, B. Kriemann, J Savolainen, S. SchlÖmer, C. von Stechow, T. Zwickel and J.C. Minx (eds.)] Cambridge University Press, Cambridge, United Kingdom and New York, NY, USA.

Jackson, M.L. (1973). Soil chemical analysis. New Delhi, India: prentice Hall of India.

Lal, R., Follett, R.F., Stewart, B.A. and Kimble, J.M. (2007) Soul carbon sequestration to mitigate climate change and advance food security. Soil Sci., 172(12): 943-956.

Schrag, D.P. (2007) Preparing to capture carbon. Science, 315:812-813.

Srinivasa Rao, Ch., Lal R., Rao, A.S., Kundu, S., Prasad Babu, M.B.B., Venkateswarlu, B. and Singh, A.K. (2014). Soil carbon sequestration in rainfed production systems in the semiarid topics of India. Cci. Tot. Environ., 487:587-603.

Srinivasarao, Ch., Lal R., Rao, A.S. Kund, S., Sahrawat, K.L., Chary, G, R., Thakur, P.B. and Srinivas, K. (2016). Carbon manaement as key to climate resilient Agriculture. (Eds. Venkateswarulu B) Climate Resilient Agronomy, Indian Society of Agronomy, 182-202.

Srinivasarao, Ch., Venkateswarlu, B., Lal, T., SINGH, S.K. and Kundu, S. (2013). Sustainable management of dryland ecosystems of India for enhancing Agronomic productivity, sequestering carbon (Sparks, D.L., Eds.) Adv. Agron., Pp. 253-329.

Walkley, A. and Black, C.A. (1934). Estimation of organic carbon by chromic acid Titration method. Soil Science, 37:29-38.

WMO (2013). World Meteorological Organization Greenhouse Gas Bulletin. Geneva, p.4.

\section{How to cite this article:}

Aminuddin Qureshi, Amrinder Kumar and Jeevan Lal Nag. 2018. Precision Agriculture and Carbon Sequestration - Need of an Hour in Current Climate Changing Scenario. Int.J.Curr.Microbiol.App.Sci. 7(02): 1668-1673. doi: https://doi.org/10.20546/ijcmas.2018.702.202 